\title{
Writing Instructions at a University and Identity Issues: A Systemic Functional Linguistics Perspective
}

\author{
https://doi.org/10.3991/ijet.v16i06.19485 \\ Nagina Kanwal \\ University of the Punjab Jhelum Campus, Jhelum, Pakistan \\ Fatima Jinnah Women University Rawalpindi, Pakistan \\ Samina Amin Qadir \\ Fatima Jinnah Women University Rawalpindi, Pakistan \\ Kamran Shaukat ${ }^{(凶)}$ \\ The University of Newcastle, Newcastle, Australia \\ kamran. shaukateuon.edu.au
}

\begin{abstract}
In this paper, we explore the discoursal identity in the academic writing of a postgraduate student from the University of Pakistan where English is the medium of instruction as well as taught as a foreign language. The study aims to find out the extent and the specific ways dominant conventions and practices enable and constrain meaning-making. It also helps to identify the role of social and institutional goals in shaping the discoursal identity of students. To achieve our objectives, we have conducted a linguistic analysis of the student's academic texts by using Systemic Functional Linguistics. The findings from the linguistic analysis of academic texts are quite significant because the lexico-grammatical and discoursal choices in the academic texts reflect their writer's desired disposition and their orientation within academia and their socio-cultural setting. Thus they reveal the writer's discoursal identity and his positioning and affiliation with the academic community. The findings of the study provide significant implications for the reconceptualization of writing instructions at universities, also they point to the need to employ emerging technologies in the writing instructions program while not ignoring the students' identity issues.
\end{abstract}

Keywords-Academic writing, Discoursal identity, Higher education, Writing instructions, Systemic Functional Linguistics

\section{$1 \quad$ Introduction}

Writing is a dominant form of social action in academic institutions and also has an essential role in creating a particular identity. Discoursal Identity refers to the impression that writers convey consciously or unconsciously through their pieces of writing. Ivanic describes this aspect of identity as 'discoursal' because 'it is constructed through the discourse characteristics of a text, which relate to values, beliefs, and 
power relations in the social context in which they were written' [1]. As Lea and Street argue, 'examining student writing within both an epistemological and an institutional frame offers a more complex way of addressing what is commonly regarded as 'problems with student writing"' [2]. While learning to write at university, students get involved in creating a new identity in line with the teachers' expectations as well as the institutional norms. The authors' overt presence or non-presence builds an academic identity and a voice with which to present an argument. However, for second/foreign-language students creating or adopting such an identity is not an easy task, partially due to the difference in the level of familiarity with these identities which do not match with the familiar identities of their everyday lives, or earlier learning experiences [3].

In university classrooms, students signify the diversity of experience and expectations as they bring with them their linguistic and educational histories and their aspirations. Owoseni, et al. [4] state that student's academic performance could be determined well by measuring their learning environment, their socio-cultural background, the existing teaching practices in the institutions, and most of all students' motivation for learning. While projecting their voice in their writing, students have to conform to the institutional norms set for academic literacy. As Barton [5] asserts, 'Socially powerful institutions, such as education, tend to support dominant literacy practices' ( $p$. 26). Lilly argues that the state of students' writing in higher education is generally described in deficit terms - students' cannot write - and writing is usually reduced to specific ideological framings of text, however vague, such as spelling and grammar.

Our research aims to gain insights into the construction of discoursal identity in academic writing of the postgraduate students. It focuses on texts; therefore, student's academic texts are gained for linguistic analysis. It also encompasses broader considerations of the socio-cultural background, the institutional norms, and power relationships within an institution and hence their influence on writing and identity. Aiswal \& Al-Hattami [6] stresses the need to understand the students' learning experiences and the way knowledge and content are structured as these are the key factors in any student-centered learning environment. Since we want to gain deep insights into the phenomenon in question; therefore the sample is small, and only one participant is chosen for the study. Holland et al. say that 'People tell others who they are, but even more importantly, they tell themselves and then try to act as though they are who they say they are' [7].

\subsection{Academic writing and higher education}

Writing is central to higher education programs; the current study is concerned with complexities involved in academic writing. The literature on writing in higher education informs that the problem of writing in academia is not solely a linguistic one (Boughey, 2000; Briane, 2002; Cummins 1989a, b; Curry, 2004; Hawkins, 2004; Hirst, Henderson, Allan, Bode, \& Kocatepe, 2004; Lea \& Street, 2006) but is also caused by the students' unfamiliarity with academic discourses (Boughey, 2000; Lea \& Street, 2000 cited in [8]). The literature also advocates that students should become acculturated (cultural modification/ assimilation) to academic discourses. 
The study is mainly influenced by Ivanic's seminal work on discoursal construction of identity (1998) and in her developing the questions of writing and identity. In her research on writing, Ivanic explored many areas, including academic writing, children's writing, adult learners, bilingual issues, and further education, ESOL students. She has always conducted her research in her immediate contexts. She contributed to the discipline of education by using her knowledge of linguistics in addressing educational problems [9].

Several kinds of research (Taylor, 1998; Lea 1994; Lea and Street, 1998) explore the breach in the relationship between the teachers' expectations and students' understanding of those expectations in academic writing. Students are generally told and are expected to provide some claims, maybe some abstract principles, and then to align them with supporting arguments, concrete examples [10]. English [11], in her study, investigates meaning-making in students' texts to look at the difference between students' understanding of what is called an appreciable, valuable work and that of the teachers or by implication institutional expectations. Her study focuses on the written work of a Japanese student; her approach for analysis of the data is descriptive, sort of a close text analysis found in functional linguistics (e.g., Halliday \& Hasan 1976; Kress \& Hodge 1983; Halliday 1985). English [11] establishes that by using this approach, the students could be encouraged to recognize their problems and thereby take control of their writing.

Hamilton \& Pitt [12] address issues of creativity and identity in academic writing and link it with Ivanic's study of academic writers and their struggles with identity in the process of writing. Latif, et al. [13] focus upon the students in foreign universities and explore how students in foreign universities could improve their learning while retaining their sense of cultural identity. They also propose that the supervisors could help the students to achieve a sense of belonging by improving their communication with them. Lea [14] focuses on the texts of online discussion as an important form of academic writing, and draws upon the established methods of academic literacies research, and uses a range of textual resources including the students' assessed texts and tutors feedback on the texts around writing for her textual investigation.

\section{Research Methodology}

The research participant chosen for the study is a postgraduate student from the Department of Linguistics, University of Gujrat. The study aims to examine the discoursal construction of student's identity in academic writing and to identify the role of social and institutional goals in shaping the literate identity of the student. To achieve this purpose, the following data is obtained.

\subsection{One complete assignment and Midterm exam paper}

The academic texts obtained for the study include one complete assignment and mid-term exam paper from the same course, i.e., Critical Discourse Analysis. We first obtained consent from the subject teacher to provide us with the academic texts for 
my research. The class assignment was assigned and evaluated by his teacher; the topic was of the student's own choice. He wrote it entirely 'naturalistically' in the sense that the writer did not know at the time of writing that the assignment would become the object of research. The second academic document which we have obtained for our study is the mid-term exam of our participant for a similar course.

\subsection{Theoretical framework}

Systemic Functional Linguistics is used for linguistic analysis of the texts; the methodology adopted is associated with Critical Discourse Analysis and Systemic Functional Linguistics: studying a text to identify traces of discourses and genres [15].

\subsection{Systemic Functional Linguistics (SFL)}

Systemic Functional Linguistics (SFL) is used widely in language education and for doing discourse analysis; this approach was developed during the 1960s mainly by M.A.K. Halliday. SFL focuses more on the functions and uses of a language than the language structure and language composition. Since our purpose is to decipher the lexicogrammatical and discourse-level features of the students' texts to see how these texts index the social practices and positioning of their writers. Therefore, we have taken short extracts from the assignment and exam paper of my research participant to identify the linguistic features which characterize his writing as 'academic discourse'. Figure 1 presents a graphical representation of the features taken from Halliday's Systemic Functional Linguistics for the linguistic analysis in the present work. 

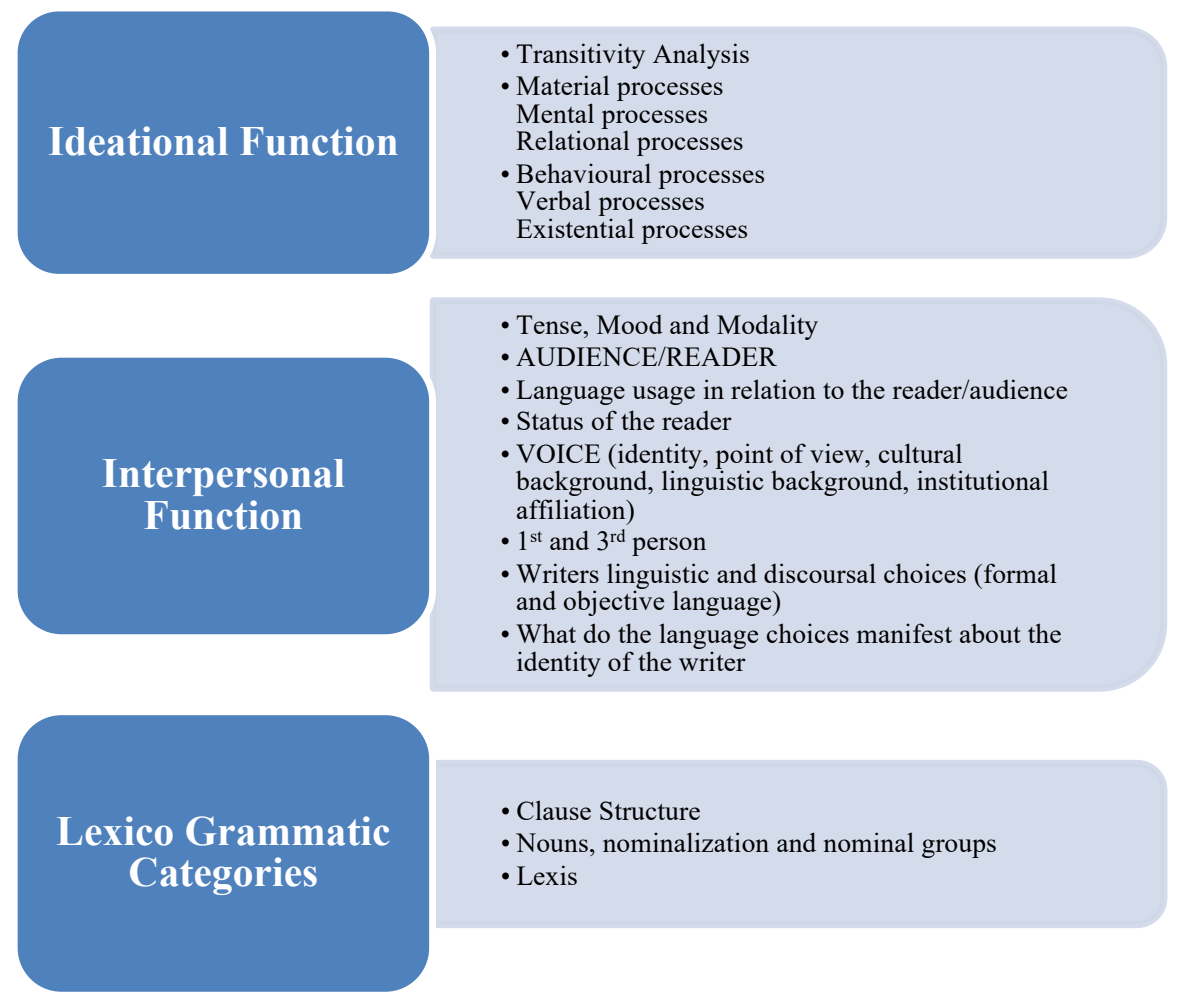

Fig. 1. Systemic Functional Linguistics Features

\section{$3 \quad$ Data Analysis and Findings}

The data is collected from the student's academic texts and the findings from the linguistic analysis of the data are presented in this section.

\subsection{Linguistic analysis of texts by using systemic functional linguistics}

The linguistic analysis of texts is taken up to illustrate the writer's positioning within the academic community and to understand the extent the writer has taken on the institutional identity. Five lexico-grammatical categories are chosen from Halliday [16], Ivanic [17] used these categories in her study of writing and identity, and we have adopted these to study my sample. We have selected short extracts of approximately 50 words from both the assignment and the exams paper and carried out their linguistic analysis by applying the selected five linguistic features. Extract A is from the assignment, and extract $\mathrm{B}$ is from the paper. 


\subsection{Extracts from the student's assignment and exam paper}

\section{Extract A (Score: 26/30) \\ Title: Speech Analysis in Critical Discourse Analysis}

The analysis of the text (speech) using Fairclough's framework reveals that it is fairly easily possible to conduct a discourse analysis with his model to uncover the features of a text and the effects such as thinking and actions. The analysis of vocabulary, grammar, and textual structures can establish and bring to the surface the hidden aspects of a text that relate to identity, discursive practices, social relations, power relations, and, more importantly, ideological underpinnings and considerations.

\section{Extract B}

Course Title: Critical Discourse analysis

Q. Explain how Critical Discourse analysis is an interdisciplinary approach to the study of discourse that views language as a form of social practice.

Score: $(3.5 / 05)$

Though all social practices are not linguistics. Therefore CDA studies discourses in its social context and tries to explain how language plays a role in the exercise and maintenance of power. CDA attempts at raising the consciousness of people considering that consciousness is the first step towards emancipation. (48 words, lines 14-22)

\section{Clause structure:}

Academic writing differs from other types of writing in terms of the clause structures and the amount of information packed into these clauses. It could be studied by calculating the lexical density of each clause, which is "the average number of lexical words per clause" [17]. The low lexical density is considered to be that of 2 or below, whereas high lexical density comprises of 5 or more [17]. Bazif's writing demonstrates the high level of lexical density of 7.2 in the assignment and 5.1 in the exam paper, which directly places him as identifying with the norms of the academic community and of the one who adopts an institutional voice. As table 1 demonstrates:

Table 1. Lexical Density in Clauses

\begin{tabular}{|c|c|c|c|c|c|c|c|c|}
\hline \multirow{2}{*}{ Writer } & \multicolumn{2}{|c|}{ Extract } & \multicolumn{2}{c|}{ No. of lexical items } & \multicolumn{2}{c|}{ No. of clauses } & \multicolumn{2}{c|}{ lexical density } \\
\cline { 2 - 9 } & $\boldsymbol{A}$ & $\boldsymbol{B}$ & $\boldsymbol{A}$ & $\boldsymbol{B}$ & $\boldsymbol{A}$ & $\boldsymbol{B}$ & $\boldsymbol{A}$ & $\boldsymbol{B}$ \\
\hline Bazif (student) & 5.8 & 5.8 & 37 & 26 & 5 & 5 & 7.2 & 5.1 \\
\hline
\end{tabular}

2. Verbs (Process Types):

The verbs found in the main and subordinate clauses are:

Extract A: Reveals, is, can establish, bring to the surface, relate

Extract B: Are, studies, tries, attempts, is

Mainly the verbs are definite and are in the present tense. As the figure shows, mainly the verbs fall into the category of mental and relational processes, which indi- 
cate that the writers are concerned with facts, states of affairs, and relationships among abstract ideas and entities. Table 2 illustrates the verbs categorized into different verb processes as given by Halliday.

Table 2. Verb Processes

\begin{tabular}{|l|c|l|c|}
\hline \multicolumn{1}{|c|}{ Mental } & \multicolumn{1}{|c|}{ Relational } & \multicolumn{1}{c|}{ Verbal } & Material \\
\hline $\begin{array}{l}\text { Reveals, can establish, tries } \\
\text { to explain }\end{array}$ & Is, relate, are, studies, is & Bring to surface & \\
\hline
\end{tabular}

3. Nouns, Nominalization, and Nominal Groups:

The nouns mentioned in these extracts are mainly inanimate, which are abstract nouns referring to theories, terms, concepts, and so forth. In the case of animate nouns, the reference is to writers and theorists of their particular discipline. The 'head nouns,' i.e., the main subject or object of the verbs, are cited below.

Extract A: Framework, analysis, text, vocabulary, grammar, structures, identity, practices, relations,

Extract B: Practices, linguistics, CDA, discourses, language, role, power, people, consciousness, emancipation

The study of these extracts further reveals that the writers have applied a discourse characteristic of compacting information in long nominal groups, "Halliday's definition of a nominal group is the head noun and everything modifying it, including any embedded clauses" [17]. We have also identified two long nominal groups of clauses from Bazif's assignment having $46 \%$ and $66 \%$ of lexical words, and the longest nominal group from his exam paper carries $69 \%$ of lexical words. Thus, indicating a hallmark of academic writing and the extent to which students embrace it to establish themselves as members of the academic community.

A1: It is fairly easily possible to conduct a discourse analysis with his model to uncover the features of a text and the effects such as thinking and actions. (28 words, $46 \%$ lexical words)

A2: The analysis of vocabulary, grammar, and textual structures can establish and bring to the surface the hidden aspects of a text that relate to identity, discursive practices, social relations, power relations. (29 words, $66 \%$ lexical words)

B: CDA attempts at raising the consciousness of people considering that consciousness is the first step towards emancipation. (16 words, 69\% lexical words)

The longest nominal groups vary in length in terms of the number of words and the lexical words used in them; they range from 14 to 29 words and $71 \%$ to $39 \%$ of lexical words. The writings of my participant reflect this practice of writing in dense clauses, which position him as a learner in the academic community as a minimum.

\section{Tense, Mood, and Modality:}

The study of tense, mood, and modality demonstrates that the dominant tense in both of these extracts is present tense, which signifies eternal truths and the writers' interest in those truths. The dominant mood used in these extracts is declarative, and no instance of imperative or interrogative mood is spotted. It exemplifies another trait 
of academic discourse where the information, facts, and ideas are presented to influence the readers' beliefs. However, an instance of a modalized verb is also identified and is listed below, which refers to a categorical standpoint:

Extract A: Modalized verb: Can establish, present tense, declarative sentences, no interrogatives, no imperatives

Extract B: Present tense, declarative sentences, no interrogatives, no imperatives

\section{Lexis:}

The term lexis refers to the use of those words and terminologies which are associated with the academic community, including the use of prepositions, nominalizations, carrier nouns, and lexical items. Our participant's writing also features the use of such terms and vocabulary items, which could establish his affiliation with the academic community and to his discipline thereof. The following are the lexical items chosen from Bazif's writing, which establish him as a member of the academic community.

Extract A: Text, Fairclough, model, reveals, conduct, discourse analysis, uncover, features, analysis, vocabulary, grammar, structure, establish, bring to the surface, hidden aspects, identity, discursive practices, ideological underpinnings, considerations

Extract B: Social practices, linguistics, discourses, social context, maintenance, raising consciousness, emancipation, Social practices, linguistics, discourses

By using these words, the writers demonstrate their affiliation with the academic community, and with their discipline, by choosing to express in this way, they also convey an impression of being comfortable with such discourse. The study of lexicogrammatical categories demonstrates the writer's positioning and affiliation with the academic community. As Ivanic [1] suggested that the lexico-grammatical conventions are related to certain interests, values, and practices, and while talking about discoursal construction of writer's identity, we would say that the writer by following these conventions consciously or unconsciously is identifying himself with those interests, values, beliefs, and practices.

\section{Discussion and Conclusion}

The findings from the linguistic analysis of academic texts are quite significant because these choices reflect their writer's desired disposition and their orientation within academia and their socio-cultural setting. The lexico-grammatical characteristics of my participant's writing reflect his affiliation with the academic community and his positioning within it. The high lexical density, the mental and relational verb processes, using abstract nouns, the long nominal groups, and the use of lexis establish it. Further characteristics of his writing include citing published authors to provide authenticity to his work in academic discourse. There are no instances of first or secondperson pronouns in his writing as he preferred to distance himself from his writing and presented his findings and viewpoints in a cold, matter-of-fact way. There is absolutely no trace of personal feelings or emotions to be seen in any writing. Also, the 
use of passive voice is noticeable, which is also used as a technique to present information and ideas in a style peculiar to academic discourse, and thus by doing so, the writer is sharing a value common in discourses of academia.

The findings of the study provide significant implications for the reconceptualization of writing instructions at universities, also they point to the need to employ emerging technologies in the writing instructions program while not ignoring the students' identity issues. The awareness of writers' identity would prove to be significant in teaching writing and an important program in writing research. The study has an implication for future researchers that they need to explore 'identity-related' issues and characteristics at a broader scale in different multilingual settings and different genres, including public, professional, academic, and personal. Research about identity in writing must take into account the context of the reader-writer interaction and the process of identity construction within it, as Matsuda asserts, 'identity is a complex phenomenon, and as such, research methods and assessment rubrics will also need to reflect the complexity' [18].

\section{$5 \quad$ References}

[1] Ivanic, R. (1998) Writing and identity: The Discoursal Construction of Identity in Academic Writing. Philadelphia: John Benjamins Publishing Company. 32-270. https://doi.org/10.1075/swll.5

[2] Lea, M. \& Street, B. (1998) Student Writing In Higher Education: An Academic Literacies Approach. Studies in Higher Education, Vol. 23 Issue 2. 3. https://doi.org/10.1080/ 03075079812331380364

[3] Cadman, K. (1997). Thesis Writing for International Students: A Question of Identity. English for Specific Purposes, Vol. 16. 1. 3-14. https://doi.org/10.1016/s08894906(96)00029-4

[4] Owoseni, A. Ibem,E. \& Opoko, A.(2020). Socio-Economic Profiling of Students and its Impact on Learning Outcomes . International Journal of Emerging Technologies in Learning. Vol 15, No.19.) https://doi.org/10.3991/ijet.v15i19.14649

[5] Barton, D. (2006) Significance of a Social Practice View of Language, Litearcy and Numeracy. In Tett, L., Hamilton, M., Yvonne, H. (Eds.) Adult Literacy, Numeracy and Language. Policy, Practice and Research. New York: Open University Press. McGraw-Hill Education. 26

[6] Aiswal, P. \& Al-Hattami, A. (2020). Enhancing Learners' Academic Performances Using Student Centered Approaches. International Journal of Emerging Technologies in Learning. Vol. 15, No.16. https://doi.org/10.3991/ijet.v15i16.14875

[7] Pahl, K. \& Rowsell, J. (2005). Literacy and Education. Understanding the New Literacy Studies in the Classroom. London: Paul Chapman Publishing. 3-11. https://doi.org/10.4135/ $\underline{9781473915237}$

[8] Malhami, A. A. (2015) Academic Literacies as Documenting Becoming Trough Mixed Genre Texts. ElectronicThesis and Dissertation Repository. Paper 2834 
[9] Barton, D. (2009) Roz Ivanic's Writing and Identity. In Carter, A., Lillis, T. \& Parkin, S. (Eds.) Why Writing Matters. Issues of Access and Identity in Writing Research and Pedagogy. Amsterdam / Philadelphia: John Benjamins Publishing Company. https://doi.org/10. 1075/swll.12.01bar

[10] Street, B. V. (1999).Academic Literacies. In Jones, C. Joan Turner, J. \& Street, B. (Eds.). Students Writing in the University Cultural and Epistemological Issues. Vol. 8. Amsterdam/Philadelphia : John Benjamins Publishing Company.

[11] English, F. (1999) What Do Students Really Say In Their Essays? Towards a Descriptive Framework for Analysing Student Writing. In Jones, C. Joan Turner, J. \& Street, B. (Eds.). Students Writing in the University Cultural and Epistemological Issues. Vol. 8. Amsterdam/Philadelphia : John Benjamins Publishing Company. https://doi.org/10.107 5/swll.8.07eng

[12] Hamilton, M. \& Pitt, K. Creativity in academic writing, Escaping from the straitjacket of genre? In Carter, A., Lillis, T. \& Parkin, S. (Eds.) (2009) Why Writing Matters. Issues of access and identity in writing research and pedagogy. Philadelphia: John Benjamins Publishing Company. 61-151. https://doi.org/10.1075/swll.12.12ham

[13] Latif, Y. Harrison, N. \& Chu, Hye-Fun. (2020). Interpreting the Cultural and Academic Experiences of PhD Students from the Indian Sub-Continent and the Chinese Regions in Australian Universities. International Journal of Emerging Technologies in Learning. 15 (19). https://doi.org/10.3991/ijet.v15i19.15799

[14] Lea, M. R. (2009). Writers and meaning making in the context of online learning. In Carter, A., Lillis, T. \& Parkin, S. (Eds.) (2009). Why Writing Matters. Issues of Access and Identity in Writing Research and Pedagogy. Amsterdam / Philadelphia: John Benjamins Publishing Company. https://doi.org/10.1075/swll.12

[15] Lillis, T. Bringing writers' voices to writing research, Talk around texts. In Carter, A. Lillis, T. \& Parkin, S. (Eds.) (2009) Why Writing Matters. Issues of access and identity in writing research and pedagogy. Philadelphia: John Benjamins Publishing Company. 184. https://doi.org/10.1075/swll.12.24lil

[16] Halliday, M. A. K. (1994). An Introduction to Functional Grammar (2 ${ }^{\text {nd }}$ Ed.). London: Edward Arnold.

[17] Ivanic, R. (1998) Writing and identity: The Discoursal Construction of Identity in Academic Writing. Philadelphia: John Benjamins Publishing Company. 32-270. https://doi.org/10.1075/swll.5

[18] Matsuda, P. K. (2015) Identity in Written Discourse. Annual Review of Applied Linguistics, 35. Cambridge University Press. pp. 140-159. doi: 10.1017/S0267190514000178

\section{Authors}

Nagina Kanwal has been working as a full-time Lecturer (English) at the University of the Punjab Jhelum Campus, Pakistan. She is currently enrolled in Ph.D. (Linguistics) Program at Fatima Jinnah Women University, Rawalpindi, Pakistan; she has a strong research interest in the field of Applied Linguistics, Discourse Analysis, and Multilingualism \& Academic Literacies. kanwalamjadd@gmail.com 
Professor Dr. Samina Amin Qadir did her Ph.D. in Linguistics from the University of Lancaster, England. Her master's in TEFL is from the University of Cardiff, Wales, UK. She has 42 years of teaching experience at the post-grad level in three different universities in Pakistan. She has served for eight years as the ViceChancellor of Fatima Jinnah Women University, Rawalpindi, Pakistan.

Kamran Shaukat is a Ph.D. student at The University of Newcastle, Australia. kamran.shaukat@uon.edu.au

Article submitted 2020-10-27. Resubmitted 2020-12-03. Final acceptance 2020-12-05. Final version published as submitted by the authors. 